\title{
Chemical composition and rumen degradability of byproducts available in the Amazon region
}

\section{Composição química e degradabilidade ruminal de subprodutos disponíveis na região Amazônica}

\author{
Ernestina Ribeiro dos Santos Neta ${ }^{1 *}$; Luis Rennan Sampaio Oliveira ${ }^{1}$; Rafael \\ Mezzomo; Daiany Íris Gomes ${ }^{1}$; Janaina Barros Luz; Dayana Lima Maciel; \\ Kharina Romana da Silva Santana ${ }^{4}$, Kaliandra Souza Alves ${ }^{1}$
}

\begin{abstract}
This study evaluated the chemical composition and ruminal degradability of dry matter (DM), neutral detergent fiber corrected for ash and protein (NDFap) and crude protein (CP) in byproducts of African oil palm (palm cake, kernel or fiber), macaúba (pulp cake and kernel cake), acai (acai fruit), babassu (kernel cake) and pineapple (peel, crown and bagasse silage). Nineteen rumen-fistulated sheep were kept in individual stalls, receiving a daily diet composed of elephant grass silage and corn and soybean concentrate. After preparation in nylon bags, the byproduct samples were incubated for $0,3,6,12,16$, $18,24,48,72,96,120$ and 144 hours, with three replicates of each ingredient per incubation time. The divergence between the protein nutritional value and energy nutritional value, based on discriminatory variables between groups, was estimated by cluster analysis. The effective degradability of DM, NDFap and $\mathrm{CP}$ for the different byproducts was, respectively, 35.9, 26.9 and $59.0 \%$ for palm cake; $48.3,34.3$ and $76.4 \%$ for palm kernel; $21.1,6.6$ and $50.3 \%$ for palm fiber; $34.3,15.0$ and $52.8 \%$ for macaúba pulp cake; $58.1 ; 63.0$ and $51.6 \%$ for macaúba kernel cake; $49.7,49.6$ and $41.8 \%$ for babassu cake; $53.4,40.5$ and $79.8 \%$ for pineapple bagasse silage; and 21.3, 17.0 and $38.9 \%$ for acai fruit. Based on their NDFap and $\mathrm{CP}$ characteristics, the feeds were clustered in up to four different groups.
\end{abstract}

Key words: Alternative feeds. Degradation. Ruminant nutrition.

\section{Resumo}

Avaliou-se a composição química e a degradabilidade ruminal da matéria seca (MS); fibra em detergente neutro (FDNcp) e da proteína bruta (PB) dos subprodutos oriundos do dendê (torta, amêndoa e fibra de dendê), macaúba (torta de polpa e torta de amêndoa), açaí (caroço de açaí), babaçu (torta da amêndoa) e abacaxi (casca, coroa e bagaço ensilado). Foram utilizados 9 ovinos fistulados no rúmen mantidos em baias individuais, recebendo diariamente dieta composta por silagem de capim elefante e concentrado a base de milho e soja. Após preparados em sacos de nylon as amostras dos subprodutos foram incubadas nos tempos de incubação $0,3,6,12,16,18,24,48,72,96,120$ e 144 horas, utilizando-se três repetições de cada alimento em cada tempo de incubação. A divergência do valor nutricional proteico e do valor

\footnotetext{
${ }^{1}$ Profs., Universidade Federal Rural da Amazônia, UFRA, Campus de Parauapebas, Parauapebas, PA, Brasil. E-mail: tina.neta@ yahoo.com; ernestina.santos@ufra.edu.br; rennanvet@yahoo.com.br; mezzomo@zootecnista.com.br; daiany.i.gomes@gmail. com; kaliandra.souza.alves@gmail.com

2 Dra em Saúde e Produção Animal na Amazônia, UFRA, Belém, PA, Brasil. Email: janaina.ufra@hotmail.com

3 Discente do Programa de Pós-Graduação em Produção Animal na Amazônia, Universidade Federal Rural da Amazônia, UFRA, Campus de Parauapebas, Parauapebas, PA, Brasil. E-mail: dayanalimamaciel@hotmail.com

4 Zootecnista, UFRA, Campus de Parauapebas, Parauapebas, PA, Brasil. E-mail: kharinaromana.ss@gmail.com

* Author for correspondence
} 
nutricional energético, baseada em variáveis discriminatórias entre os grupos, foi estimada por meio de análise de agrupamento. A degradabilidade efetiva da MS, FDNcp e PB dos diferentes subprodutos foram, respectivamente, de 35,9; 26,9 e 59,0\% para torta de dendê, 48,$3 ; 34,3$ e 76,4\% para amêndoa de dendê, 21,$1 ; 6,6$ e 50,3\% para fibra de dendê, 34,$3 ; 15,0$ e $52,8 \%$ para a torta de polpa de macaúba, 58,$1 ; 63,0$ e $51,6 \%$ para a torta de amêndoa de macaúba, 49,$7 ; 49,6$ e 41,8\% para torta de babaçu, 53,4 ; 40,5 e 79,8\% para silagem de resíduo de abacaxi, 21,3; 17,0 e 38,9\% para o caroço de açaí. Com base nas características da FDNcp e da PB os alimentos foram agrupados em até quatro grupos distintos.

Palavras-chave: Alimentos alternativos. Degradação. Nutrição de ruminantes.

\section{Introduction}

The use of alternative feeds in diets can improve the quantity and quality of ruminant feed by including regional byproducts purchased at low cost to replace traditional ingredients, such as corn and soybean meal, among other ingredients of high commercial value. Therefore, many studies have been conducted in recent years to assess whether these byproducts can be used without negatively affecting animal production (LUZ et al., 2017; ELIYAHU et al., 2015; ABUBAKRET al., 2013; HABIB et al., 2013).

The Amazon flora provides a wide diversity of raw materials, including the African oil palm (Elaeis guineensis), acai (Euterpe oleracea, Mart.), macaúba (Acrocomia aculeata (lacq)), babassu (Orbignya speciosa, Mart.) and pineapple (Ananas comosus); these materials generate processing byproducts, such as cakes, seeds, peels, bagasse and crowns, that can be used in animal feed. The use of byproducts in animal feed has certain disadvantages, such as variation in chemical composition due to inadequate quality control; however, the availability and low cost of these ingredients throughout the year reduce production costs and therefore favor their inclusion in ruminant diets. Nevertheless, questions still frequently arise regarding the use of these ingredients, such as the choice of byproduct, whether to substitute the roughage or the concentrate and the ratio to be used in the diet (SANTOS et al., 2016).

In addition to the availability and cost throughout the year, the chemical composition of each ingredient should be determined to improve its characterization and the use of its nutrients. This determination produces important information to generate Brazilian food composition tables, thus facilitating the dietary inclusion of an ingredient in the field. Among the available food evaluation techniques, in situ degradation has stood out because this technique allows a determination of the fractions, rates and extent of ruminal feed degradation, predicting the availability of a certain nutrient (AZEVEDO et al., 2012; NOCEK, 1988) and thus the feasibility of its use in complete diets.

The aim of the present study was to evaluate the chemical and bromatological composition and the ruminal degradability of dry matter (DM), crude protein $(\mathrm{CP})$ and neutral detergent fiber corrected for ash and protein (NDFap) in palm, macaúba, babassu, pineapple and acai processing byproducts.

\section{Materials and Methods}

The protocol used in this study conforms with the ethical principles for animal experimentation of the Conselho Nacional de Controle de Experimentação Animal (National Council for Control of Animal Testing) and was approved by the Comissão de Ética no Uso de Animais (Animal Research Ethics Committee) of the Universidade Federal Rural da Amazônia (Federal Rural University of the Amazon), UFRA, Brazil (003/2014).

The experiment was conducted in the Small Ruminants Sector of the Food Analysis Laboratory, UFRA, on the Parauapebas Campus, located in the southeast region of Pará State, Brazil (latitude 0604'16.4'S, longitude 04949'8.3”W, altitude $270 \mathrm{~m})$. 
From the fruits of African oil palm (Elaeis guineensis), the experiment used the full kernel, the cake resulting from the extraction of palm kernel oil and the fiber byproduct of palm oil extraction derived from fruit pulp processing. From macaúba (Acrocomia aculeate (lacq)), the experiment used the cake resulting from pulp processing and that resulting from kernel oil extraction; from acai (Euterpe oleracea, Mart.), the experiment used the fruit, with the pulp removed, that consisted of the mesocarp, endocarp and seed and was ground before predrying; from babassu (Orbignya sp.) the experiment used the cake resulting from kernel oil extraction; and from pineapple (Ananas comosus), the experiment used peel, crown and bagasse silage.

The samples were predried in a forced-air oven $\left(55^{\circ} \mathrm{C}\right)$, pre-degreased (palm cake and kernel, macaúba pulp cake and kernel cake) and then divided into two subsamples, which were processed in a knife mill with 1- or 2-mm mesh sieves. Samples of $1 \mathrm{~mm}$ were evaluated for DM (INCT-AC L-003/1), CP (INCT-CA C-001/1), ether extract (INCTAC L-004/1), NDFap (INCT-Ac F-001/1), acid detergent fiber (INCT-Ac F-005/1), lignin (INCTAc F-005/1) and non-protein nitrogen (INCT-CA N-002/1) contents according to Detmann et al. (2012). Subsequently, the total digestible nutrient levels of the feeds were estimated according to the BR-Corte 3.0 recommendation (VALADARES FILHO et al., 2016).

The indigestible neutral detergent fiber (NDFi) was quantified by the ruminal incubation of the samples $(2 \mathrm{~mm})$, according to the methodology described by Valente et al. (2011).

For evaluating the DM, NDFap and CP degradation profiles, nine castrated, male, crossbred, Santa Inês sheep, weighing $43.77 \pm 2.82$ $\mathrm{kg}$, were used. The sheep were rumen fistulated and subsequently housed individually in $1.0-\mathrm{x} 2.0-\mathrm{m}$ metabolic cages provided with feeding and drinking troughs. Daily in the morning (8:00 am) and in the afternoon $(4: 00 \mathrm{pm})$, the animals were fed a diet containing $17.63 \% \mathrm{CP}$ and a roughage: concentrate ratio of 50:50, with the roughage consisting of elephant grass silage and the concentrate consisting of corn, soybean meal and mineralized salt; a maximum leftover level of $10 \%$ was established.

For incubating the samples, nylon bags (50 $\mu \mathrm{m})$ that measured $10 \times 20 \mathrm{~cm}$ and had been previously identified, washed, dried and weighed were prepared; and the ground material $(2 \mathrm{~mm})$ was added while maintaining a surface area coverage of $20 \mathrm{mg} \mathrm{cm}^{2-1}$ (VALENTE et al., 2011). Incubation times of $0,3,6,12,16,18,24,48,72,96,120$ and 144 hours were evaluated, with three replicates of each feed per incubation time, for a total of 324 samples. For each animal to incubate only 11 bags at a time, the feed was evaluated in trios, so that at each evaluation time, the samples of each feed were incubated in three animals. The samples were fixed with nylon thread to a steel chain with a weight at its end, allowing sample immersion in the ruminal content. The bags were transferred into the rumen in reverse order to the incubation time, so that their removal occurred simultaneously. Immediately after their removal from the rumen, the bags were washed in running water until the water was completely clear and then transferred to a forced-air oven at $55^{\circ} \mathrm{C}$ for approximately 72 hours.

To determine the soluble fractions, the bags containing samples for time zero were also subjected to the same washing and drying procedures as those of the remaining samples. The undegradable DM was obtained by difference between the sample weight pre- and postincubation and drying of the sample in a non-ventilated oven $\left(105^{\circ} \mathrm{C}\right)$. Next, $\mathrm{CP}$ and NDFap were analyzed in the incubation residues, according to Detmann et al. (2012).

The DM, NDFap and CP degradation profiles were estimated using the first-order asymptotic model reparametrized by Ørskov and McDonald (1979) and described by the following function: $\mathrm{Yt}$ $=\mathrm{A}+\mathrm{B} \times\left(1-\mathrm{e}^{(-\mathrm{kd} \times \mathrm{t})}\right)$, where $\mathrm{Yt}=$ fraction degraded at time $t ; A=$ soluble fraction; $\mathrm{B}=$ potentially 
degradable insoluble fraction; $\mathrm{kd}=$ degradation rate of $\mathrm{B}$ : and $\mathrm{t}=$ independent time variable. The undegradable fraction $(\mathrm{C})$ was calculated by the following equation: $\mathrm{C}=100-\mathrm{A}-\mathrm{B}$.

The Statistical Analysis System (SAS) procedure PROC NLIN was used to estimate the parameters $\mathrm{A}, \mathrm{B}$ and $\mathrm{kd}$, assuring that when $\mathrm{A}+\mathrm{B}$ totaled more than $100 \%$, the parameters were corrected proportionally so as not to total more than $100 \%$.

The effectively degraded fraction of DM, NDFap and $\mathrm{CP}$ was calculated by the model $\mathrm{DE}=[\mathrm{A}+(\mathrm{B} \times$ $\mathrm{kd}) /(\mathrm{kd}+\mathrm{kp})]$; where $\mathrm{kp}$ is the rate of feed passage through the rumen, considering three rates: 2, 5 and $8 \%$ /hour, corresponding to low, medium and high intake, respectively, as proposed by ARC (1984).

The rumen-degradable protein (RDP) fraction was measured from the analysis of the feed sample residues incubated for 16 hours in the rumen, according to Calsamiglia and Stern (1995).

The results are presented descriptively, performing a simple and direct numerical evaluation via pairwise comparisons between the Amazon byproducts. Cluster analysis was also performed to estimate the divergence of the protein and energy nutritional values between byproduct groups, based on discriminatory variables, applying the Mahalanobis generalized distance (SINGH, 1981). The cluster analyses were performed via the Genes System (CRUZ, 1998).

\section{Results and Discussion}

The ingredients obtained from the processing of fruit kernels showed the highest CP contents, especially the palm cake, palm kernel, macaúba kernel cake and babassu cake, with protein levels above $11 \%$ (Table 1). With the exception of babassu cake these byproducts also showed the highest ether extract contents, evidencing that relatively efficient processing for oil extraction results in a relatively high CP content of DM. However, the use of ingredients with high ether extract content can limit DM intake and alter ruminal fermentation; thus, their use in diets should be limited.

Table 1. Chemical composition (\% DM) of byproducts available in the Amazon region.

\begin{tabular}{|c|c|c|c|c|c|c|c|c|c|c|c|c|}
\hline Item & $\mathrm{DM}$ & $\mathrm{OM}$ & $\mathrm{CP}$ & $\mathrm{EE}$ & NDFap & $\mathrm{ADF}$ & NFC & NDIP & Lignin & NDFi & TDN & NPN \\
\hline Palm cake & 89.4 & 91.9 & 11.2 & 19.8 & 42.1 & 33.2 & 18.9 & 56.0 & 9.8 & 31.1 & 85.7 & 10.9 \\
\hline Palm kernel & 77.7 & 97.0 & 14.2 & 28.2 & 53.1 & 40.7 & 1.6 & 16.0 & - & 10.8 & 69.3 & 85.9 \\
\hline Palm fiber & 91.9 & 93.4 & 6.7 & 8.5 & 57.8 & 54.4 & 20.5 & 46.1 & 22.6 & 41.5 & 40.4 & 3.8 \\
\hline Macaúba pulp cake & 87.5 & 97.2 & 4.8 & 23.2 & 51.8 & 41.4 & 17.5 & 28.0 & 26.6 & 42.9 & 90.6 & 16.4 \\
\hline $\begin{array}{l}\text { Macaúba kernel } \\
\text { cake }\end{array}$ & 60.2 & 97.2 & 25.7 & 19.2 & 512 & 325 & 12 & 468 & 80 & 101 & 76.2 & 19.0 \\
\hline Babassu cake & 86.9 & 95.3 & 19.8 & 6.8 & 62.7 & 33.7 & 6,0 & 47.9 & 9.5 & 30.0 & 30.2 & 12.5 \\
\hline $\begin{array}{l}\text { Pineapple bagasse } \\
\text { silage }\end{array}$ & 15.6 & 92.9 & 9.6 & 3.2 & 51.9 & 36.5 & 28.2 & 14.3 & 4.7 & 26.2 & 65.9 & 83.8 \\
\hline Acai fruit & 72.5 & 98.4 & 5.3 & 1.5 & 79.5 & 61.5 & 12.1 & 66.8 & 8.5 & 31.1 & 18.1 & 12.9 \\
\hline
\end{tabular}

DM: Dry matter; OM: Organic matter; CP: Crude protein; EE: Ether extract; NDFap: Neutral detergent fiber corrected for ash and protein; ADF: Acid detergent fiber; NFC: Non-fiber carbohydrates; NDIP: Neutral detergent insoluble protein (as a percentage of $\mathrm{CP}$ ); NDFi: Indigestible neutral detergent fiber; TDN: Total digestible nutrients; NPN: Non-protein nitrogen (as a percentage of $\mathrm{CP})$. 
Except for the palm kernel and pineapple bagasse silage, the byproducts generally presented a high content of neutral detergent insoluble protein (Table 1), which may reduce nutrient use by ruminal microorganisms. Although RDP is important to meet the demands of microbiota, numerous efforts sometimes exist to reduce protein degradability in the rumen and thus meet metabolizable protein requirements through digestibility at the intestinal level. For this reason, feeds with a low ruminal degradation rate and high digestibility, such as babassu cake, are good options for inclusion in ruminant diets, especially ruminants with a high performance level, which requires relatively high metabolizable protein levels.

After the palm kernel, the macaúba pulp cake, despite its fruit mesocarp derivation, was the byproduct with the second highest ether extract content (Table 1). Two probable explanations exist to explain this pattern. One possibility is that the moisture content in the raw fruit is much higher in the pulp than in the kernel (CICONINI et al., 2013; DESSIMONI-PINTO et al., 2010), making oil extraction more difficult. Another possibility is that compared with the kernel, the macaúba pulp is richer in oils in some regions of Brazil, probably due to the soil, climate and variety conditions; and this proportion can be maintained in byproducts, as observed in the present study for the macaúba pulp and kernel (Table 1).

The ether extract content found in the macaúba pulp cake is close to the $21.4 \%$ value obtained by Sobreira et al. (2012) and above the $14.95 \%$ value determined by Azevedo et al. (2012). This difference emphasizes the need for prior and constant analysis of byproducts before their use in feed formulations, due to the large percentage variability found in different studies.

All the byproducts, except the palm cake, showed NDFap contents above $50 \%$, with the acai fruit exhibiting the highest content $(79.48 \%)$. This result is among those that deserve special attention regarding the use of these byproducts as a substitute for feeds traditionally used in ruminant diets, such as soybean meal and corn (with average NDFap contents of 14.63 and $14.08 \%$, respectively).

The high values of NDFap found in these byproducts are closer to the $72.03-73 \%$ values observed for elephant grass silage (GUERRA et al., 2016), traditionally used as dietary roughage. However, although such high values are usually associated with poor food quality, the main decisive point is not merely the neutral detergent fiber content of a particular ingredient but how this ingredient interacts with microbial enzyme systems, which are responsible for its degradation and use. Therefore, the potentially degradable fraction of neutral detergent fiber is an important energy source, and its importance as the main source of energy for animal production systems in the tropics should be emphasized (LAZZARINI et al., 2009).

The high levels of neutral detergent fiber and ether-extractable material caused a reduction in the non-fiber carbohydrate content of the byproducts, especially palm kernel (1.6\%) and macaúba kernel cake (1.2\%), the byproducts with the lowest levels. Although most of the ingredients studied have shown non-fiber carbohydrate levels above $12 \%$, these levels are far below those found in corn and soybean meal. Nevertheless, these ingredients can be important sources of non-fiber carbohydrates when the byproduct is used as a substitute for roughage; at a level of $28.2 \%$, the pineapple bagasse silage stands out for this application.

Regarding DM degradability, similar degradation curves were observed for the macaúba kernel cake, pineapple bagasse silage, babassu cake and palm kernel. These byproducts also presented the highest soluble fractions and high potentially degradable DM fractions (Table 2). The DM degradation rate for these byproducts exceeded $50 \%$ during the first 48 hours of incubation. Only at 80 hours of incubation did palm cake exhibit the same degradation level as that of the other byproducts, even though palm 
cake had the highest potentially degradable fraction $(62.3 \%)$; this pattern occurred because of the slow degradation rate $(1.1 \%)$ of the palm cake and its low soluble fraction.

Table 2. Estimate of dry matter (DM) degradation and effective degradability parameters for byproducts available in the Amazon region.

\begin{tabular}{lccccccc}
\hline \multirow{2}{*}{ Byproduct } & \multicolumn{3}{c}{ Degradability of DM (\%) } & \multicolumn{4}{c}{ Effective degradability of DM (\%) } \\
\cline { 2 - 7 } & $\mathrm{A}$ & $\mathrm{B}$ & $\mathrm{C}$ & $\begin{array}{c}\mathrm{Kd} \\
\left(\% \text { hour }^{-1}\right)\end{array}$ & ${ }^{1}$ 2\%/h & ${ }^{1} 5 \% / \mathrm{h}$ & ${ }^{1} 8 \% / \mathrm{h}$ \\
\hline Palm cake & 13.7 & 62.3 & 24.0 & 1.1 & 35.9 & 25.0 & 21.3 \\
Palm kernel & 26.0 & 59.6 & 14.4 & 1.2 & 48.3 & 37.3 & 33.8 \\
Palm fiber & 11.8 & 15.9 & 72.3 & 2.8 & 21.1 & 17.5 & 15.9 \\
Macaúba pulp cake & 22.0 & 21.7 & 56.3 & 6.6 & 38.7 & 34.4 & 31.8 \\
Macaúba kernel cake & 42.9 & 53.6 & 3.5 & 0.8 & 58.1 & 50.2 & 47.7 \\
Babassu cake & 27.3 & 49.9 & 22.9 & 1.6 & 49.7 & 39.6 & 35.8 \\
Pineapple bagasse silage & 33.5 & 43.4 & 23.1 & 1.7 & 53.4 & 44.5 & 41.1 \\
Acai fruit & 13.6 & 12.6 & 73.8 & 3.2 & 21.3 & 18.5 & 17.2 \\
\hline
\end{tabular}

$\mathrm{A}=$ soluble fraction; $\mathrm{B}=$ potentially degradable fraction; $\mathrm{C}=$ undegradable fraction; Kd: Fractional rate of degradation; ${ }^{1}$ Passage rate (ARC, 1984).

By contrast, the palm fiber, macaúba pulp cake and acai fruit reached the maximum DM degradation point at 96 hours of incubation, with only $21.1,38.7$ and $21.3 \%$ effective degradation, respectively, considering a slow rate of passage (2\%/hour) (Table 2). Given the negative correlation of DM degradability with lignin content and NDFi as well as the observation that lignin is the factor with the greatest effect on the extent and rate of DM degradation (COSTA et al., 2016), the above DM degradation results can be attributed to the lignin and NDFi levels in the byproducts. The palm fiber and macaúba pulp cake byproducts had the highest observed lignin contents (Table 1), providing a barrier that restricted the activity of the digestive enzymes produced by the ruminal microorganisms and thus leading to low degradability. The acai fruit presented low lignin content $(8.5 \%)$ but a high content of NDFi (31.1\%), with the latter promoting reduced DM degradation.

Regarding the ruminal NDFap degradation parameters, the palm byproducts (palm cake, palm kernel and palm fiber) were observed to have the lowest soluble NDFap fractions $(0.6,0.5$ and $0.9 \%$, respectively) (Table 3 ). The macaúba kernel cake presented the largest soluble fraction, followed by the babassu cake and pineapple bagasse silage, resulting in the three highest NDFap degradation rates compared with the other byproducts in the first hours of incubation.

The palm kernel had the highest value for the potentially degradable NDFap fraction among the evaluated feeds. By contrast, the lowest potentially degradable NDFap fractions were found for the macaúba pulp cake, acai fruit and palm fiber. These byproducts also exhibited the largest undegradable fractions (Table 3 ). For the macaúba pulp cake and palm fiber, these results are most likely due to their high lignin content (Table 1) that impedes access by microorganisms to the cell matrix. In addition, the degree of chemical interaction of lignin with phenolic and glycosidic compounds is an important factor in the degradability of fiber components (DETMANN et al., 2004). Thus, the lignin in the acai fruit most likely affected the low degradability of NDFap. 
Furthermore, the highest NDFi levels were observed for the macaúba pulp cake, acai fruit and palm fiber: $42.9,31.1$ and $41.5 \%$, respectively. This set of factors explains the low NDFap degradation recorded for these byproducts, which can be confirmed by the effective degradability values found for the macaúba pulp cake (15.0\%), acai fruit $(17.0 \%)$ and palm fiber $(6.6 \%)$ at the low passage rate of $2 \%$ per hour, with more significant reductions at the higher passage rates (Table 3 ).

Table 3. Estimate of neutral detergent fiber degradability and effective degradability parameters for byproducts available in the Amazon region.

\begin{tabular}{lccccccc}
\hline \multirow{2}{*}{ Byproduct } & \multicolumn{3}{c}{ Degradability of NDFap (\%) } & \multicolumn{3}{c}{ Effective degradability (\%) } \\
\cline { 2 - 7 } & $\mathrm{A}$ & $\mathrm{B}$ & $\mathrm{C}$ & $\begin{array}{c}\mathrm{Kd} \\
\left(\% \mathrm{hour}^{-1}\right)\end{array}$ & ${ }^{1}$ 2\%/h & ${ }^{1}$ 5\%/ h & ${ }^{1}$ 8\%/h \\
\hline Palm cake & 0.6 & 57.4 & 42.0 & 1.7 & 26.9 & 15.1 & 10.6 \\
Palm kernel & 0.5 & 83.5 & 16.0 & 1.4 & 34.3 & 18.4 & 12.7 \\
Palm fiber & 0.9 & 16.3 & 82.9 & 1.1 & 6.6 & 3.8 & 2.8 \\
Macaúba pulp cake & 3.3 & 13.0 & 83.8 & 18.9 & 15.0 & 13.5 & 12.4 \\
Macaúba kernel cake & 32.7 & 44.9 & 22.4 & 4.1 & 63.0 & 53.0 & 48.0 \\
Babassu cake & 26.1 & 44.0 & 29.9 & 2.3 & 49.6 & 39.9 & 35.9 \\
Pineapple bagasse silage & 17.41 & 52.5 & 30.1 & 1.6 & 40.5 & 30.0 & 26.0 \\
Acai fruit & 11.2 & 14.1 & 74.7 & 1.4 & 17.0 & 14.3 & 13.3 \\
\hline
\end{tabular}

NDFap: Neutral detergent fiber corrected for ash and protein; NDFi: Indigestible neutral detergent fiber; $\mathrm{A}=$ soluble fraction; $\mathrm{B}$ = potentially degradable fraction; $\mathrm{C}=$ undegradable fraction; Kd: Fractional rate of degradation; ED: Effective degradability; ${ }^{1}$ Passage rate (ARC, 1984).

Based on the characteristics of carbohydrates, macaúba kernel cake and babassu cake are apparently the most suitable byproducts for use in feed formulations. Despite their high NDFap contents, the degradation rates of these byproducts are also high, as shown by their effective degradability values. Thus, the NDFap digestibility of these byproducts together with their EE contents (19.2 and $6.8 \%$, respectively) could possibly compensate energetically for their low non-fiber carbohydrate contents (Table 1).
The byproduct-derived feeds were sorted into four distinct groups (Table 4), considering the data for potentially digestible neutral detergent fiber, the sum of the A+B fraction and the potentially digestible DM. Palm kernel (group IV) could be classified as the best feed because of its highest contribution of NDFap and potentially digestible DM as well as its largest sum of soluble and potentially soluble NDFap fractions. When considering these same characteristics, the group composed of palm cake, palm fiber and macaúba pulp cake (group II) can be considered the one of lowest nutritional quality (Table 4). 
Table 4. Byproduct clustering considering neutral detergent fiber corrected for ash and protein (NDFap) ${ }^{1}$.

\begin{tabular}{lccccc}
\hline \multicolumn{1}{c}{ Group } & GI & GII & GIII & GIV & $\begin{array}{c}\text { Contribution } \\
\text { of variables }\end{array}$ \\
\hline NDFpd (\% NDFap) & 54.8 & 23.7 & 60.9 & 79.7 & 23.50 \\
A+B (\%) & 72.5 & 30.5 & 25.3 & 84.0 & 2.96 \\
DMpd (\% DM) & 70.2 & 60.5 & 68.5 & 88.3 & 73.52 \\
NDFap & 55.2 & 50.5 & 79.5 & 53.1 & - \\
NDFi & 25.1 & 38.5 & 31.0 & 10.8 & - \\
A & 18.2 & 1.6 & 11.2 & 0.5 & - \\
B & 47.2 & 28.9 & 14.1 & 83.5 & - \\
C & 27.5 & 69.6 & 74.7 & 16.0 & - \\
Kd (\%hour ${ }^{-1}$ ) & 2.7 & 7.2 & 1.4 & 1.4 & - \\
${ }^{2} \mathrm{ED} \mathrm{2 \% /h}$ & 51.0 & 16.2 & 17.0 & 34.3 & - \\
${ }^{2} \mathrm{ED} \mathrm{5 \% /h}$ & 41.0 & 10.8 & 14.3 & 18.4 & - \\
${ }^{2} \mathrm{ED} \mathrm{8 \% /h}$ & 36.6 & 8.6 & 13.3 & 12.7 & - \\
\hline & - Macaúba kernel cake & - Palm cake & - Acai & - Palm & \\
& - Babassu cake & - Palm fiber & fruit & kernel & \\
\hline
\end{tabular}

${ }^{1}$ Mean value for groups; ${ }^{2}$ Passage rate (ARC, 1984).

One of the two intermediate groups comprises macaúba kernel cake, babassu cake and pineapple bagasse silage (group I), with characteristics very similar to the best group (palm kernel). The other intermediate group contains only acai fruit (group III) and shows a high but largely unusable NDFap content (Table 4).

Regarding the CP degradation parameters, the pineapple bagasse silage showed the largest soluble fraction among the byproducts $(69.9 \%)$ and the second smallest undegradable fraction (10.5\%), resulting in the highest effective degradability rate $(79.8 \%$ for a passage rate of $2 \%$ per hour). Considering that the pineapple silage presented a high non-protein nitrogen content $(83.8 \%$ of $\mathrm{CP})$
(Table 1) and that in this case, soluble fractions correlate with feed degradation, $75 \%$ degradation at 16 hours after incubation was enabled for the pineapple bagasse silage. Similarly, the palm kernel, with an approximately $60 \%$ soluble fraction and a low undegradable fraction (12.7\%), showed effective degradability values exceeding $76 \%$. This behavior is important because the high degradation rate associated with other parameters indicates that the protein in byproducts is responsible for the rapid rate of ruminal degradation. These results are confirmed by the finding that the highest RDP percentages (75.7 and $72.5 \%$ ) were observed for pineapple bagasse silage and palm kernel, respectively (Table 5). 
Table 5. Estimate of crude protein degradability and effective degradability parameters for byproducts available in the Amazon region.

\begin{tabular}{|c|c|c|c|c|c|c|c|c|c|}
\hline \multirow[b]{2}{*}{ Byproduct } & \multirow[b]{2}{*}{$\mathrm{RDP}$} & \multirow[b]{2}{*}{ RUP } & \multicolumn{4}{|c|}{ Degradability of CP (\%) } & \multicolumn{3}{|c|}{ Effective degradability (\%) } \\
\hline & & & A & B & $\mathrm{C}$ & $\begin{array}{c}\text { Kd } \\
\left(\% \text { hour }^{-1}\right)\end{array}$ & ${ }^{1} 2 \% / \mathrm{h}$ & ${ }^{1} 5 \% / \mathrm{h}$ & ${ }^{1} 8 \% / \mathrm{h}$ \\
\hline Palm cake & 46.5 & 53.5 & 30.2 & 61.4 & 8.3 & 1.8 & 59.0 & 46.2 & 41.3 \\
\hline Palm kernel & 72.5 & 27.5 & 60.2 & 27.2 & 12.7 & 3.0 & 76.4 & 70.3 & 67.5 \\
\hline Palm fiber & 45.2 & 54.8 & 35.7 & 21.2 & 43.1 & 4.4 & 50.3 & 45.6 & 43.2 \\
\hline Macaúba pulp cake & 44.5 & 55.5 & 30.9 & 38.7 & 30.5 & 2.6 & 52.8 & 44.2 & 40.4 \\
\hline Macaúba kernel cake & 48.6 & 51.4 & 44.4 & 41.5 & 14.1 & 0.4 & 51.6 & 47.7 & 46.5 \\
\hline Babassu cake & 28.0 & 38.3 & 13.1 & 62.7 & 24.2 & 1.7 & 41.8 & 29.0 & 24.1 \\
\hline Pineapple bagasse silage & 75.7 & 24.3 & 69.9 & 19.7 & 10.5 & 2.0 & 79.8 & 75.5 & 73.8 \\
\hline Acai fruit & 17.3 & 82.7 & 33.7 & 8.1 & 58.2 & 3.5 & 38.9 & 37.1 & 36.2 \\
\hline
\end{tabular}

RDP: Rumen-degradable protein (\% of DM); RUP: Rumen-undegradable protein ( $\%$ of DM); A = soluble fraction; $\mathrm{B}=$ potentially degradable fraction; $\mathrm{C}=$ undegradable fraction; ${ }^{1}$ Passage rate (ARC, 1984).

However, even with a percentage of effective protein degradation lower than that of the pineapple bagasse silage and palm kernel, the macaúba kernel cake proved superior to the other ingredients tested, since its protein levels (25.7\%) and its degradation rate indicate that compared with the other ingredients, this cake better meets the protein requirements of ruminal microorganisms.

The babassu cake showed the lowest soluble fraction (13.1\%), whereas the acai fruit presented the lowest potentially degradable fraction $(8.09 \%)$, resulting in low effective degradation $(41.8 \%$ for the babassu cake and $38.9 \%$ for the acai fruit, with a passage rate of $2 \%$ per hour). These results arise from the high content of protein complexed to the cell wall, hindering access by ruminal microorganisms. The chemical composition of the byproducts illustrates this situation, where the babassu cake, acai fruit and palm cake presented high values for neutral detergent insoluble protein: 47.9, 66.8 and 56.0\%, respectively (Table 1).

The palm fiber and the macaúba pulp cake showed a soluble fraction of 35.7 and $30.9 \%$, respectively; however, as the potentially degradable fraction was low $(21.2,38.7 \%)$, the protein degradation rate stabilized rapidly.

Considering the crude protein content and the potentially degradable fraction of the crude protein of the byproducts, four groups of foods were obtained (Table 6). The best group (group I) was composed of macaúba kernel cake and babaçu cake, and the worst group was composed of açaí stone, palm fiber, and macaúba pulp cake (group IV). These results possibly occurred in detriment of the low crude protein content and the finding that most of the protein in this byproduct is in a rumenundegradable form. 
Table 6. Byproduct clustering considering crude protein ${ }^{1}$.

\begin{tabular}{lccccc}
\hline Group & GI & GII & GIII & GIV & $\begin{array}{c}\text { Contribution of } \\
\text { variables }\end{array}$ \\
\hline CP & 22.7 & 12.7 & 9.6 & 5.6 & 43.9 \\
B (\% DM) & 11.5 & 5.4 & 1.9 & 1.2 & 56.1 \\
A+B & 80.9 & 89.5 & 89.5 & 56.1 & \\
A & 28.8 & 45.2 & 69.9 & 33.4 & \\
B & 52.1 & 44.3 & 19.7 & 22.6 & \\
C & 19.1 & 10.5 & 10.5 & 43.9 & 3.5 \\
Kd (\%hour $\left.{ }^{-1}\right)$ & 1.1 & 2.4 & 2.0 & 47.3 & \\
${ }^{2}$ ED 2\%/h & 46.7 & 67.7 & 79.8 & 42.3 & \\
${ }^{2}$ ED 5\%/h & 38.3 & 58.3 & 75.5 & 73.0 & \\
${ }^{2}$ ED 8\%/h & 35.3 & 54.4 & - Palm fiber & \\
\hline & - Macaúba ker- & - Palm cake & - Pineapple ba- & - Macaúba pulp \\
& nel cake & - Palm kernel & gasse silage & cake & \\
& - Babassu cake & & & - Acai fruit & \\
\hline
\end{tabular}

CP: Crude protein (\% of DM); $\mathrm{B}=$ potentially degradable fraction $(\%$ of $\mathrm{DM}) ; \mathrm{A}=$ soluble fraction; $\mathrm{B}=$ potentially degradable fraction; $\mathrm{C}=$ undegradable fraction; $\mathrm{Kd}=$ crude protein degradation rate; ${ }^{1}$ Mean value for groups; ${ }^{2}$ Passage rate (ARC, 1984).

\section{Conclusion}

Macaúba kernel cake, babassu meal, palm kernel and pineapple bagasse silage showed the greatest potential for use in animal feed due to their chemical and bromatological compositions and degradability rates. Palm fiber, macaúba pulp cake and acai fruit exhibited a high lignin content and/or low degradability rates, suggesting a lower potential for use in animal feed compared with the other byproducts tested.

\section{Acknowledgments}

The authors thank CNPq for research funding, the Universidade Federal Rural da Amazônia/ Parauapebas Campus for providing research facilities and to the students who helped with field experiments.

\section{References}

ABUBAKR, A. R.; ALIMON, A. R.; YAAKUB, H.; ABDULLAH, N.; IVAN, M. Growth, nitrogen metabolism and carcass composition of goats fed palm oil by-products. Small Ruminant Research, Amsterdam, v. 112, n. 1, p. 91-96, 2013. DOI: org/10.1016/j. smallrumres.2012.11.003

AGRICULTURAL RESEARCH COUNCIL - ARC. Nutrient requirements of ruminant livestock. Slough: London: CAB, 1984. Supplement 1.

AZEVEDO, R. A.; RUFINO, L. M. A.; SANTOS, A. C. R.; SILVA, L. P.; BONFA, H.; DUARTE, E. R.; GERASSEV, L. C. Desempenho de cordeiros alimentados com inclusão de torta de macaúba na dieta. Pesquisa Agropecuária Brasileira, Brasília, v. 47, n. 11, p. 1663-1668, 2012.

CALSAMIGLIA, S.; STERN, D. A three-step in vitro procedure for estimating intestinal digestion of protein in ruminants. Journal of Animal Science, Champaign, v. 73 , n. 5, p. 1459-1465, 1995. DOI: org/10.2527/1995.7351459x

CICONINI, G.; FAVORO, S. P.; ROSCOE, R.; MIRANDA, C. H. B.; TAPETI, C. F.; MIYAHIRA, M. A. M.; BEARARI, L.; GALVANI, F.; BORSATO, A. V.; NAKA, M. H. Biometry and oil contents of Acrocomia 
aculeata fruits from the Cerrados and Pantanal biomes in Mato Grosso do Sul, Brazil. Industrial Crops and Products, Amsterdam, v. 45, n. 1, p. 208-214, 2013. DOI: 10.1016/j.indcrop.2012.12.008

COSTA, R. F.; PIRES, D. A. A.; MOURA, M. M. A.; RODRIGUES, J. A. S.; ROCHA JÚNIOR, V. R. R.; TOLENTINO, D. C. In situ degradability of dry matter and fibrous fraction of sorghum silage. Acta Scientiarum. Animal Sciences, Maringá, v. 38, n. 2, p. 171-176, 2016. DOI: $10.4025 /$ actascianimsci.v38i2.29576

CRUZ, C. D. Programa GENES: aplicativo computacional em estatística aplicada à genética (GENES - Software for Experimental Statistics in Genetics). Genetic Molecular Biology, São Paulo, v. 21, n. 1, pp.-., 1998. DOI: 10.1590/ S1415-47571998000100022

DESSIMONI-PINTO, N. A. V.; SILVA, V. M.; BATISTA, A. G.; VIEIRA, G.; SOUZA, C. R.; DUMONT, P. V.; SANTOS, G. K. M. Características físico-químicas da amêndoa de macaúba e seu aproveitamento na elaboração de barras de cereais. Alimentação e Nutrição, Araraquara, v. 21 , n. 1, p. $79-86,2010$.

DETMANN, E.; SOUZA, M. A.; VALADARES FILHO, S. C.; QUEIROZ, A. C.; BERCHIELLI, T. T.; SALIBA, E. O. S.; CABRAL, L. S.; PINA, D. S.; LADEIRA, M. M.; AZEVEDO, J. A. G. Métodos para análise de alimentos. Visconde do Rio Branco: Suprema, 2012. 214 p.

DETMANN, E.; ZERVOUDAKIS, J. T.; CABRAL, L. S.; ROCHA JÚNIOR, V. R.; VALADARES FILHO, S. C.; QUEIROZ, A. C.; PONCIANO, N. J.; FERNANDES, A. M. Validação de equações preditivas da fração indigestível da fibra em detergente neutro em gramíneas tropicais. Revista Brasileira de Zootecnia, Viçosa, MG, v. 33, n. 6, p. 1866-1875, 2004. Suplemento 1.

ELIYAHU, D.; YOSEF, E.; WEINBERGD, Z. G.; HEN, Y.; NIKBACHAT, M.; SOLOMON, R.; MABJEESH, S. J.; MIRON, J. Composition, preservation and digestibility by sheep of wetby-products from the food industry. Animal Feed Science and Technology, Amsterdam, v. 207, n. 1, p. 1-9, 2015. DOI: 10.1016/j. anifeedsci.2015.05.005

GUERRA, D. G. F.; MAIA, I. S. A. S.; BRAGA, A. P.; ASSIS, L. C. S.; LUCENA, J. A.; BIDLER, D. C.; SANTOS NETO, C. F.; SILVA, Y. F. M.; PEREIRA, M. I. B.; PINTO, M. M. F. Chemical composition of elephant grass silages supplemented with different levels of dehydrated cashew bagasse. Semina: Ciências Agrárias, Londrina, v. 37, n. 2, p. 997-1006, 2016. DOI: 10.5433/1679-0359.2016

HABIB, G.; KHAN, N. A.; ALI, M.; BEZABIH, M. In situ ruminal crude protein degradability of by products from cereals, oilseeds and animal origin. Livestock Science Journal, Amsterdam, v. 153, n. 1, p. 81-87, 2013. DOI: 10.1016/j.livsci.2013.01.017

LAZZARINI, I.; DETMANN, E.; SAMPAIO, C. B.; PAULINO, M. F.; VALADARES FILHO, S. C.; SOUZA, M. A.; OLIVEIRA, F. A. Dinâmicas de trânsito e degradação da fibra em detergente neutro em bovinos alimentados com forragem tropical de baixa qualidade e compostos nitrogenados. Arquivo Brasileiro de Medicina Veterinária e Zootecnia, Belo Horizonte, v. 61, n. 3, p. 635-647, 2009.

LUZ, J. B.; ALVES, K. S.; MEZZOMO, R.; SANTOS NETA, E. R.; GOMES, D. Í.; OLIVEIRA, L. R. S.; SILVA, J. C.; CARVALHO, F. F. R. Carcass characteristics and meat quality of lambs fed babassu cake (Orbignya speciosa) as a replacement for elephant grass silage. Tropical Animal Health and Production, Edinburgh, v. 49, n. 1, p. 113-119, 2017. DOI: 10.1007/ s11250-016-1167-6

NOCEK, J. E. In situ and other methods to estimate protein and energy digestibility. A review. Journal of Dairy Science, Champaign, v. 71, n. 8, p. 2051-2069, 1988. DOI: $10.3168 /$ jds.S0022-0302(88)79781-7

ØRSKOV, E. R.; McDONALD, I. The estimation of protein degradability in the rumen from incubation measurements weighed according to rate of passage. Journal of Agricultural Science, Cambridge, v. 92, n. 2, p. 499-503, 1979. DOI: 10.1017/S0021859600063048

SANTOS, C. R.; ALVES, K. S.; MEZZOMO, R.; OLIVEIRA, L. R. S.; CUTRIM, D. O.; GOMES, D. I.; LEITE, G. P.; ARAÚJO, M. Y. S. Performance of feedlot lambs fed palm kernel cake-based diets. Tropical Animal Health and Production, Edinburgh, v. 48, n. 2, p. 367372, 2016. DOI: 10.1007/s11250-015-0960-y

SINGH, D. The relative importance of characters affecting genetic divergence. Indian Journal of Genetics and Plant Breeding, Indian, v. 41, n. 2, p. 237-245, 1981.

SOBREIRA, H. F.; LANA, R. P.; MANCIO, A. B.; FONSECA, D. M.; MOTOIKE, S. Y.; SILVA, J. C. P. M.; GUIMARÃES, G. Casca e coco de macaúba adicionada ao concentrado para vacas mestiças lactantes em dietas à base de silagem de milho. Revista Brasileira de Agropecuária Sustentável, Brasília, v. 2, n. 1, p. 113117, 2012. DOI: $10.21206 /$ rbas.v2i1.65

VALADARES FILHO, S. C.; COSTA E SILVA, L. F.; LOPES, S. A. BR-CORTE 3.0. Cálculo de exigências nutricionais, formulação de dietas e predição de desempenho de zebuínos puros e cruzados. [S.1.: s.n.], 2016. Available at: www.brcorte.com.br. Accessed at: 10 jan. 2017. 
VALENTE, T. N. P.; DETMANN, E.; VALADARES FILHO, S. C.; CUNHA, M.; QUEIROZ, A. C.; SAMPAIO, C. B. In situ estimation of indigestible compounds contents in cattle feed and feces using bags made from different textiles. Revista Brasileira de Zootecnia, Viçosa, MG, v. 40, n. 3, p. 666-675, 2011. 